\title{
The Error Analysis on the Students of English Department Speaking Scripts
}

\section{Setia Rini}

Sekolah Tinggi Agama Islam Negeri (STAIN) Salatiga

Jl. Tentara Pelajar No.02 Salatiga, Central Java, Indonesia

setiarini.setia@gmail.com

\begin{abstract}
Speaking skill is different from writing skill. Writing is a formal skill, so as a writer he or she must be consistently follow the formal procedures. It is different from the speaking skill which doesn't so strict in accommodating the formal rules. The Writing of script at Speaking 2 lecture is the focus of this study because the scripts are presented after they prepare for having conversation. Through writing the speaking script the students learn carefully of khow to deliver a conversation purposefully and use the language features correctly even in oral communication. Moreover, in speaking they are able to convey their feeling, emotion and thought. The purposes of this study are to know the kind of grammatical errors made by the students of the English Department in writing their speaking scripts and the sources of students in making error in writing the speaking scripts. The researcher takes the subjects of students of the second semester of the English Department STAIN Salatiga in academic year of 2012/2013 as they took Speaking 2 subject. And to collect the data the researcher used test and documentation. The result of this study explains that the writer analyzed the errors made by the students included the use of grammatical rules, vocabulary choice by implementing error analysis. In addition, the errors
\end{abstract}


are analyzed such as the use of preposition, subject pronoun, object pronoun, verbs and nouns, irregular verbs, tenses, pronouns and possessive case, word choice, writing questions, and conditional sentence.

Keywords: Error Analysis, Speaking, Writing and Script

\begin{abstract}
Abstrak
Keterampilan berbicara berbeda dari keterampilan menulis dalam pembelajaran bahasa Inggris. Menulis adalah keterampilan formal, sehingga para penulis harus konsisten untuk mengikuti prosedur resmi dalam menulis. Hal ini berbeda dengan keterampilan berbicara yang tidak mengikuti aturan formal seperti halnya keterampilan berbicara. Fokus dari penelitian ini adalah penulisan naskah speaking di mata kuliah speaking 2 yang mana nantinya naskah dibuat setelah mahasiswa mempersiapkan rancangan untuk percakapan. Dengan menulis naskah untuk berbicara mahasiswa dapat belajar dengan lebih teliti untuk berbicara atau dalam percakapan dalam bahasa Inggris dengan baik dan benar. Tujuan dari penelitian ini adalah untuk mengetahui jenis kesalahan pada tata bahasa yang ditulis oleh mahasiswa Jurusan Bahasa Inggris dalam penulisan naskah berbicara dan mengetahui penyebab kesalahan dalam menulis naskah mata kuliah Speaking 2.
\end{abstract}

Kata kunci: Kesalahan, analisis, naskah.

\title{
Introduction
}

Speaking is a skill that can be mastered through continuous practices. This skill cannot be generated genetically. Speaking skill is different from writing skill. Writing is a formal skill, so as a writer he or she must be consistently follow the formal procedures. It is different from the speaking skill which doesn't so strict in accommodating the formal rules. For instance, the discourse markers must be clearly seen 
within the text. On the other hand, in speaking the phrases can be represented by an interval when someone is speaking.

Speaking 2 is a subject covers some topic to be practiced by the second semester students of the English Department at STAIN Salatiga. In these two classes the teacher weekly asks the students to practice speaking by using Role Play Method. The students make a group of 4 or five to discuss about one topic that has been arranged and presenting each topic weekly. Before presenting their dialogue based on the scripts, the students submit also the scripts.

The focus of this study is on the writing speaking 2 scripts, because the scripts are presented after they prepare for having conversation. By writing the speaking script they learn carefully of how to deliver a conversation purposefully and use the language features correctly even in oral communication. Moreover, in speaking they are able to convey their feeling, emotion and thought.

Baker $(2011$; 13) said that the skills of language cover listening, speaking, reading and writing; meanwhile the components cover grammar, vocabulary, phonology and graphology. Those skills and components of language are related to each other. As an example when someone wants to deliver his feeling or thought by writing, he has to notice not only the vocabulary but also the grammar. In writing, as one of the components of a language, grammar is necessary in order to create meaningful and understandable sentences. Moreover, for many people, grammar is an aspect which becomes the most difficult to learn in English. 
"Grammar may be roughly defined as the way a language manipulated and combines words (or bits of words) in order to form longer units of meaning" (Ur, 2007; 4).

A language without grammar would be disorganized and causes misunderstanding, like grammatical errors in writing speaking scripts. Therefore, learners need to know the grammatical system of the language so that they can communicate with others properly. The learners frequently make mistakes and even errors in learning English, especially when they try to arrange sentences or use tenses in writing. As a result, they will write sentences grammatically incorrect.

\section{Research Methodology}

In doing this research, the data is taken from the scripts of speaking 2 classes which are submitted through email and print outs. Two Speaking 2 classes in the English Department in the second semester at STAIN Salatiga in academic year of 2012/2013 as the population of this research

As Arikunto $(2006 ; 134)$ stated that if the population is less than one hundred, the subjects should be taken entirely. Therefore, the researcher takes the subjects of students of the second semester of the English Department STAIN Salatiga in academic year of 2012/2013 as they took Speaking 2 subject and submit the scripts of the speaking 2 tests through email. The other groups of students submit the scripts in printed sheets. There are only 5 groups who submitted the scripts of speaking 2 tests through email. 


\section{Method of Data Collection}

Test

Arikunto $(2006 ; 150)$ wrote a test can be described a series of questions or other instruments, which are used to measure the intervals or group's skill, knowledge, intelligence, capability or talent. Here, the researcher uses a test as the instrument of the research. The test is given to know and to identify the errors made by students in writing the speaking II scripts.

\section{Documentation}

The researcher also collects some materials from students' speaking 2 scripts and to give suggestion for better understanding and learning. As Arikunto $(2006 ; 158)$ noted documentation, from the word document means written objects, is way to collect data from written objects such as books, magazines, documents, ordinances, notes, diaries or other documentations.

\section{Method of Data Analysis}

In this study the writer used descriptive method to solve problems in education fields for making revisions (Mohammad Ali, 1985) Meanwhile Moh. Nazir (1983) explained that this method is used to scrutinize the status of a group of people, object, condition, system of thought and recent events. It has the purpose to describe facts, characteristics of the object of the study systematically and accurately.

This is a survey research, as stated by Mohammad Ali (1985) that this kind of study is aimed at identifying a group of objects in a certain period. Furthermore Moh Nazir (1983) stated that it is used to get the 
symptoms and search for information. Analysis survey document is used to solve the problems like in descriptive study; and the object of this study is Speaking 2 Test Scripts written by students of the English Department of STAIN Salatiga.

The writer selected 5 samples of the Speaking 2 test scripts written by the students of the English Department of STAIN Salatiga in academic year 2012/2013 randomly and then the writer followed the steps started from identifying, describing, explaining, and revising the errors.

\section{Discussion}

\section{Error Analysis}

Writing in the first language is a complex process and of course, it will be more complicated to write in a foreign language. Many researchers have tried to identify the common errors made by students in writing the second language. Having better understanding of errors and the source of errors will help teachers to know students' difficulties in learning that language.

As Hydari and Bagheri (2012 cited in Keshavaez, (1999) stated that there have been two major approaches to the study of learner's errors, contrastive analysis and error analysis. However, error analysis then became the favored way of describing learner's language. The error analysis was also noted by Ellis $(1994 ; 47)$ that in the 1970s, it succeed contrastive analysis, which focus on the learner's errors by identifying the linguistic differences between learner's first language and the target language. 
The existence of error analysis is not far from the development and changes in language teaching. One of the basic changes is about the experts' paradigm on learners and language learner. Experts considered the only source of information is teachers, so language teaching and learning focuses on the teacher; it means that teacher becomes the subject and the students are the object.

According to Nababan (1993), the changes in that paradigm improve the attention on the achievement analysis toward the language target by learners in a certain time called Error Analysis. He stated that it is a proper tool to identify the achievement target on the learners' language target.

\section{Mistakes and Errors}

In language learning context, the difference between mistake and error is clearly defined. Nababan (1993) stated that differing between those terms is very crucial in language error analysis because those terms are different in concept. He said that the characteristics of mistake are that it is done unpurposively by the speaker, and he will repair by himself. Most native speakers can make mistakes, but the sooner they repairs it, the better they realize their mistakes consciously because of fatigue or sleepy.

On the contrary, Nababan (1993) stated that error is the speaker of the language target subconsciously produces the error so that he cannot repair it soon. He will always make the same errors in the oral or written work. The basic characteristic of error is that it is not done systematically by the TL (target language) speaker. It can be repaired by his teacher, native speaker or the experts. 


\section{The Steps in Doing Error Analysis}

According to Van Elk as quoted by Nababan (1993), that there are some steps in language error analysis;

a. Identifying error; Nababan (1993) stated that in this step a teacher must be sensitive in identifying the types of error and also the non structural factor, such as on fair and unfairness of forms, because target language learners will make error on the language varieties

b. Describing error; Generally, error can be explained in the form of addition, lessen, replacing the element and word order. This step must be followed by reconstructing the form of error. Reconstructing the form of error is rearranging the wrong sentences purposefully. It becomes the guidance to determine what is wrong and how to revise it.

c. Explaining error; finding the causes of error based on its classification. The advantage is that teacher can refer to which point that has most errors done by the target language learners.

d. Evaluating error; evaluating error either qualitatively

e. Revising error. revising the error by giving remedial training/teaching through focusing on general errors either on the structural contexts or unstructured elements.

It has been argued by Richards, as quoted by Nababan (1993), that there are two causes for students in making the error:

1) Error caused by the interference of the target language called interlingual errors. This error has the relevance with the negative influences of students' language in language target including phonology, morphology, syntax, lexis and culture.

2) Error caused by the difficulties faced by the students due to that 
target language, including analogi. This kind of error is called intralingual errors.

\section{The Benefit of Error Analysis}

Error analysis has its significance from the point of view of the teacher and from the learner of language. This kind of significance is seen at the peak of the sixth level, after the steps are passed. In the final steps, both students and teacher are interacting in remedial training or teaching. Students know their error and then revise it continuously.

While identifying the error, the teacher gets the advantages, but in describing the error, teachers get whether the speech are true or false. So as in explaining the error, students are able to know what is wrong and why it is wrong when teacher evaluate them. Finally, students are invited to revise their errors so that they will not encounter the same trouble again.

Nababan (1993) discovered that although there are many benefits of error analysis, then teachers may not focus on students' error. It is suggested that the four language skills can be implemented sinergically, in both oral and written forms.

\section{The Notion of Writing}

Lado (1983) explained that writing is arranging the graphical symbols that represent any language known by people to be communicated.

Bell and Burnaby, as quoted by Nunan (1989) explained that writing is a very complicated cognitive process in which the writer is required to control toward variables simultaneously. In a sentence, the 
control can be on the content, format, sentence structure, punctuation, pronunciation and letters arrangement.

\section{The Characteristic of Writing}

Nunan (1989) stated that learning to write expressively is the most difficult macro skill for language users, and ignoring whether it is a first or second or even foreign language. All children except the physically incapable ones learn to comprehend their mother tongue. Not all of them can write, but some others tries to learn to write easily.

White, as quoted by Nunan (1989) also stated that writing is not a genetic skill instead of learning how to write. Writing requires the possibility of the movable information but actually it is permanent.

\section{Basic Concept of Writing}

Writing is a process. Shoemaker (1985) defined process as a chain of events, changes or jobs which produce a result. To understand the writing process, there are many steps that lead us to the written communication like a spiral. The components are interacted continuously, or even we can do it together. For example, when the writers get an idea, they can find their focus of writing and basically, finding new ideas, making focus, explaining and revising occurs at any activities. Even though there is continuity on each component; they can be done separately by good writers.

Shoemaker (1985) in his book Write in the Corner mention that there are five assumptions about writing; (1) Writing is personal, because the main purpose of doing it is a need for self actualizing; (2) Writing is a process for better result; (3) writing is a continuous interaction between 
components; (4) in its process also covers finding ideas; dan (5) identifying the writer's procedural weaknesses than on their mistakes.

Writing is a written means of communication between the writer and the reader and it must be written clearly to avoid ambiguity. It is the way of presenting ideas. Numerous studies have attempted that those rules consist of grammar, writing style, punctuation, capitalization that lead to the purposive academic writing effectively. (Sullivan, 1984; APA, 1990; Gibaldi 1990) .

Krashen (1984) in his book Writing: Research, Theory, and Applications explained that there were many recent studies in evaluating the improvement of training in writing toward the writing skill itself. Some studies agreed on it, some others are not. The results of the effect of frequent writing compared with the effect of reading development shows that reading has great impact toward writing competence. To be a good writer must be a good reader first.

\section{Steps in Writing}

Kirszner (1983) identified that there are many steps in writing. The first is invention. At this stage a good writer has to understand with what will be written to determine the length of the text, the purposes of writing, the reader, and the whole knowledge he has. Second the arrangement, the writer has to identify about what will be written, the limitation on theme and topic through some investigative questioning, imagining, selecting and grouping ideas, also formulating the main idea. Finally is writing and revision. In this step the writer delivers his ideas and corrects the scripts. Even, a good writer makes crosschecking among his colleagues. 
Krashen (1984) observed that there are four important steps to be noticed by a good writer; the first is planning. Secondly is rescanning. Krashen stated that a good writer will always stop writing frequently for rereading during his writing. It functions to add, lessen, or revise his text. Thirdly is revision. A good writer will revise his writings many times to complete it. The final step is recursion. The writer crosses checks through non-linear approach such as by reformulating and harmonizing among those three previous steps

Considering the complexity of the writing rules, it needs regularity and consistency. Moreover doing scientific writing is not just taking shorter time and instantly. Ron White and Valerie Arndt, as quoted by Harmer (2001), stressed on rewriting and revising has important roles in writing process. They proposed that writing is a continuous activity such as; drafting, structuring, reviewing, focusing and generating ideas and evaluation

Nunan (1989) explained that those who are succeeded in mastering the writing skill are those who master word arrangement, master and obey pronunciation and punctuation, use purposive grammatical rules, organize content in the script and text to describe new information and comments, revise and complete the previous writers' activity, choose appropriate language style for the reader.

\section{The Relationship between Writing and Error Analysis}

Writing is considered as the most difficult skill among the other language skills. One of the reasons is that it is not a heritage. It needs learning and practices continuously. 
Secondly, the writer has to master and obey formally on the language rules, such as structural (grammar usage, lexical items, and punctuation) and non structural rules (ideas, language styles cohesion and coherence). Due to its formality, many students often get difficulties in writing, but they must keep on spirit to practice writing. They do not need to be afraid of making mistakes in writing processes.

In this case, teachers as facilitator invite students to analyze the errors together in class for evaluating and revising the errors done by the students' candidates in writing. Writing is a formal skill and error analysis is also a formal process to revise and improve writing skills. Through error analysis both teachers and students are able to find errors due to their mother tongue's interferences in the context of phonology, morphology, syntax, lexical and culture.

\section{Basic English Grammar}

There are many points to be discussed in Basic English Grammar. Here the writer took the source of information from http://www.englischhilfen.e/en/grammar.htm which is retrieved on the October $24^{\text {th, }} 2013$. Those points are:

a. Simple Present Tense

b. Proper names (or nouns) in English

c. Prepositions at, in, on

d. Passive Voice

e. Personal pronouns, Possessive determiners, Possessive pronouns.

f. Modals - English Grammar

g. Direct and Indirect Speech

h. Degree of Comparison

i. Simple Past Tense 
Most of the learners' errors which is found in the writing skill are in the areas of verbs (be $+\mathrm{V}$ for $\mathrm{V}$, be omission, -s omission, incorrect use of present perfect, incorrect use of past perfect), prepositions (incorrect use of prepositions, redundant prepositions), articles (omission of a, incorrect use of a, omission of the ,the instead of zero), plural/singular agreement, adjectives, conjunctions (incorrect use of conjunctions, stranded/redundant conjunctions)

\section{Data Presentation}

In the 5 samples of the Speaking 2 test scripts written by the students of the English Department of STAIN Salatiga in academic year 2012/2013. Below are data of groups of students :

\begin{tabular}{|c|l|c|l|}
\hline NO & \multicolumn{1}{|c|}{ GROUP 1. } & NO & \multicolumn{1}{|c|}{ GROUP 2 } \\
\hline 1 & Dwi Setyawan & 1 & Wakhid \\
\hline 2 & Yuyun Azizah & 2 & Yunita \\
\hline 3 & Hafizh Ana N & 3 & Hajar \\
\hline 4 & Asna Ristanti & 4 & Faisal Ariadi \\
\hline 5 & Zulia Permata Q & & \multicolumn{1}{|c|}{ GROUP 4: } \\
\hline NO & \multicolumn{1}{|c|}{ GROUP 3 } & NO & \multicolumn{1}{|c|}{} \\
\hline 1 & Nofi Yulianti & 1 & Mu'minatul afifah \\
\hline 2 & Fitriyani Masfufah & 2 & Alfida Alfiyani \\
\hline 3 & Ismiatul Faidah & 3 & Sutikno \\
\hline 4 & Dini wahyu Tri utami & 4 & Muhaimin \\
\hline 5 & Ratih Purwati & 5 & Atik Magfiroh \\
\hline NO & GROUP 5 & & \\
\hline 1 & Sapta Suci & & \\
\hline 2 & Siwi Puji Saras Wati & & \\
\hline 3 & Sachibul Ula & & \\
\hline 4 & Uswatun Hasanah & & \\
\hline \multicolumn{2}{|l|}{} & & \\
\hline
\end{tabular}

\section{Data Analysis and Discussion}

In this case the writer analyzed the errors made by the students included the use of grammatical rules, vocabulary choice by implementing error analysis theory by Brown (2000), Corder (1973), 
Ellis (1997). The errors that are analyzed such as the use of preposition, subject pronoun, object pronoun, the use of verbs and nouns, irregular verbs, tenses, pronouns and possessive case, word choice, writing questions, conditional sentence etc.

Below are some of the data of the speaking 2 tests scripts which were analyzed for its grammatical errors points.

\section{Data 1}

Then Asna come in to her house.

Mrs. Hafizh : where have you been Asna? We are worried to you.

Asna : (just silent)

Mr. Dwi : Asna, your mother asks! Why you don't answer?! it must be in past form. "Why didn't you answer?"

Asna : when mom and dad care of me?! You just care of your work! Not me!

It is a question, there must be a auxiliary. So it should be "when did mom and dad care of me?"

\section{Data 2}

Mrs. Hafizh : I'm so sorry Asna. It's all for you, for your own good.

Mr. Dwi : your mom right Asna. (It must be : Your mom is right Asna) We are care to you. (It must be : we care you)

Asna $\quad:$ what side? This?!(Show her wallet). It doesn't a real happiness dad. (Throw her wallet and go to her room).

It is a nominal sentence, it uses an adjective. So it should be "it is not a real happiness Dad". It must be "She throws her wallet and goes to her room."

\section{Data 3}

Outside of the Police Office

Hajar : then, what will we do now? back home?

Yunita : no. I am afraid of my mother if she know about this. Let's get back to palagan

"Know" must be added "s". Since the subject of the sentence is "she"

\section{Data 4}

Novi : Hai yes I am Novi, anything else

Ratih : Do you will go to fitri's house? 
This is a kind of future tense. In the question form it doesn't need an auxiliary because there is a modal "will". So the sentence should be " Will you go to Fitri's house?"

\section{Data 5}

Ismi

: Yeah like that, may be we will be confused too if we get much of bussiness beside be a teacher.

( back to imagination)

"beside be a teacher", after beside is followed by V-ing. So it should be "beside being a teacher"

\section{Data 6}

Dini : People around there looked for fish, but they just met a snake. Then they cut it into smaller pieces.

Fitri : That remain piece changed be a man, he was called Baru Klinting. He was short and had bad smell. Then he go down to the village. He wanted food, but nobody give him.

"then he go down town to the village", it should be in past tense form.

So, the word "go" should be changed to "went"

\section{Data 7}

Uswa

: I got the information yesterday, by browsing the internet. You can watch TV if you want more information.

Sapta : I've never watch television. It is boring and just wasting my time. It only full of un-useful programs and bad effect for children. So children nowadays have poor idea to playing with their friends. It must be infinitive after "to". So it should be "to play" not "to playing"

\section{Data 8}

Zulia

: you are right. But internet is the most complete media to search information.

Asna : yes. Guys, may I sleep over here?

Yuyun $\quad:$ yes, of course. You can sleep over here anytime you want.

Zulia : don't be clumsy. We are friendship right?

("Friendship" should be replaced by "Friends".)

\section{Data 9}

While Asna's parents are watching TV, Asna and her friends talk about advantages and disadvantages of watching TV. 
Asna : huh.. they always like that!

Zulia : do you know that watching TV has many disadvantages? (it needs a to be "are" after "they" because it is a nominal sentence)

\section{Data 10}

Yuyun : TV has many advantages and disadvantages. So we must be smart to choose what we want to watch from TV.

Zulia : yes I agree with you. We also must manage our time for watching TV.

Asna : that's good. If I had had TV station, I would show educating and entertaining program.

(conditional sentence type 2 , "if $+\mathrm{S}+\mathrm{V} 2+\mathrm{C}$ " so it should be " if I had TV Station")

According to the data that show some mistake in the transcript of speaking project, the researcher found that the types of errors were as follows:

1. Deletion of the indefinite article.

2. Writing "a" as part of the noun/adjective following it.

3. Use of the infinitive and gerund.

4. The use of preposition

5. The order of noun

6. The order of adjectives.

7. The use of there is/are.

8. Use of degree comparison

9. How to order the direct/indirect object.

10. How to construct of past tense, simple present

11. How to construct conditional sentence.

12. How to make passive voice. 


\section{Conclusion}

Based on the finding of the analysis, it shows that the students made errors. The dominant errors students made are error of using preposition, using noun, simple present tense, simple past tense, word choices, and degrees of comparison.

After analyzing the source of error from each various kinds of error, the researcher find that the most dominant source or error is ignorance of rule restrictions.

\section{References}

APA, 1983. Publication Manual of the American Psychological Association, Washington: APA

Brown, H. D, 1980. Principles of Language Learning and Teaching, New Jersey: Prentice Hall, Inc, Englewood Cliffs.

Gibaldi, J. 1999. MLA Handbook for Writers of Research Papers, the Modern New York: Language Association of America.

Harmer, J. 2001. The Practice of English Language Teaching, England: Longman.

Harris, D.P. 1969. Testing English as a Second Language, New York: McGraw-Hill Book Company.

Kirszner, L.G., and Stephen, R. M. 1983. Patterns for College Writing: A Rhetorical Reader and Guide, New York: St. Martin's Press.

Krashen, S.D., 1984. Writing: Research, Theory, and Applications, New York: Pergamon Institute of English.

Lado, R. 1983. Language Teaching: Scientific Approach, India: Tata McGraw-Hill Publishing Company Limited.

Mohamad, A. 1985. Penelitian Kependidikan, Prosedur dan Strategi, Bandung: Angkasa.

Nazir, M. 1988. Metode Penelitian, Ghalia Indonesia, Jakarta.

Nunan, D. 1989. Designing Task for the Communicative Classroom, Cambridege: Cambridge University Press. 
Shoemaker, C. 1985. Write in the Corner WhereYou Are, USA: HoltRinehart and Winston., Inc.

Sri, U.S. and Nababan. 1993. Metodologi Pengajaran Bahasa. Jakarta: Gramedia.

Sullivan, K.E. 1984. Paragraph Practice: Writing the Paragraph and the Short Composition, New York: Macmillan Publishing Co., Inc.

Winarno, S. 1978. Dasar dan Teknik, Research Pengantar Metodologi Ilmiah, Bandung: Tarsito. 
The Error Analysis on the Students of English Department Speaking Scripts 